\title{
細胞診断学的にみた肺巨細胞癌
}

\section{Giant cell carcinoma of the lung}

A cytological evaluation.

沢田勤也・福間誠吾・関 保雄 · 石田逸郎 · 田中文隆

田中 昇 ${ }^{*} \cdot$ 丸山孝士 ${ }^{*} \cdot$ 館崎慎一郎 ${ }^{*} \cdot$ 金 耀誠 ${ }^{*} \cdot$ 池田栄雄 $^{* *}$

抄録：肺巨細胞癌の組織像は横紋筋肉腫に類似し転移が多藏器に及ぶ悪性度の高い性格をもつ. 著者らは，本型の直接採取法による新鮮癌細胞の形態を検討した。大小不同が著しく多 核，単核巨細胞が優勢で Cytophagocytosis や有糸分裂像が多い.また細胞間結合に乏し い多角, 円型細胞もみられ，核は分葉，陥凹，出芽，〈びれなど多形性が著しい。多く の細胞は, PAS 反応陽性である.また各種の巨細胞の鑑別診断についても検討を加えた。

\section{I .はじめに}

肺巨細胞癌は, Nash \& Stout ${ }^{1)}(1958)$ にり はじめて報告された原発性肺癌の一型である。 彼らによれば, 臨床的に原発巣の局所進展が速 く, 遠隔転移が早期に招来され, かつ多臓器に わたっている. 病理組織学的には, 横紋筋肉腫 に類似し，多核巨細胞を混之，細胞間結合に乏 しいという特徵を挙げている。

その後, Bendel, ${ }^{2)}$ Hellstrom, ${ }^{3)}$ Flanagan, ${ }^{4)}$ Guillan, ${ }^{5)}$ Herman, ${ }^{6)}$ Lerner, ${ }^{7)}$ Razzuk $^{8)}$ な゙によ る多数の報告例がみられるが, いづれも他の肺 癌の組織型よりも発生年令が若年, かつ症状の 発現が急速で, 1 年以内に死亡する症例の多い ことや, 転移様相が広汎で多臓器に及ぶことに より切除率が低く, 従来, 肺癌の中で極めて悪 性度が高く, 予後不良とされている小細胞型未 分化癌よりもさらに一層子後が不良であるなど 臨床症状や所見についての注目すべき点で一致 している.

千葉県がんセンター呼吸器科

$\begin{array}{ll}* & \text { 同研究所病理研究部 } \\ * * & \text { 臨床検査部細胞診 }\end{array}$

病理組織像からみても, 横紋筋肉腫, 骨肉腫 に類似したパターンを示し, 細胞型は, 多核, 単核巨細胞が優勢を示し, Emperipolesis, ${ }^{9)} \mathrm{Cy}$ tophagocytosis の出現に特徴所見を求める報告 が多い.

著者らは, 千葉県がんセンタ一開設以来 4 年 余の内に扱った肺癌症例225例のうち, 病理組織 学的に WHO 組織分類 ${ }^{10)}$ に基づいて肺巨細胞癌 と診断された 3 例と細胞診からみて肺巨細胞癌 と診断された 2 例の計 5 例について, 臨床的事 項を背景に, 気管支鏡下擦過細胞診, 経皮的肺 穿刺細胞診による新鮮癌細胞像の検討を行ない 若干の知見をえたので報告する。

\section{II . 検索対象と方法}

a). 検索対象

Tab. 1, Tab. 2 のように年令は，41才から 70 才まで平均 58 才で, 男 4 例, 女 1 例である.

初発症状は, 気管支症状としては, 咳嗽 1 例, 血痰 3 例の外, 気管支外症状として, 胸痛, 発 熱, 倦意, 体重減少が 4 例にみられている。 胸部 X線病型は，いづれも肺野結節型である. 気管支鏡検查は5 例全例に施行されているが, 
Table 1. Clinical data in giant cell carcinoma of the lung

\begin{tabular}{|c|c|c|c|c|c|c|c|}
\hline & Age & $\operatorname{Sex}$ & Symptom & $\begin{array}{c}\text { Chest } x \text {-ray } \\
\text { Type \& Location }\end{array}$ & $\begin{array}{l}\text { Bronchoscopic } \\
\text { findings }\end{array}$ & Treatment effect & Prognosis \\
\hline Case 1 & 70 & $F$ & bloody sputum & nodular $\quad 1_{6}$ & tumor & $\begin{array}{ll}\begin{array}{l}\text { intraoperative } \\
\text { radiation } \\
\text { (excision) }\end{array} & \text { no } \\
\end{array}$ & $3^{\mathrm{mo}}$ expired \\
\hline Case 2 & 41 & M & $\begin{array}{l}\text { fatigue } \\
\text { fever }\end{array}$ & nodular $\mathrm{rS}_{1}$ & inflammation & lobectomy & $7^{\mathrm{mo}}$ alive \\
\hline Case 3 & 63 & M & $\begin{array}{l}\text { bloody sputum } \\
\text { chest pain }\end{array}$ & nodular $1_{3}$ & obstruction & radiation & $13^{\mathrm{mo}}$ expired \\
\hline Case 4 & 54 & M & $\begin{array}{l}\text { bloody sputum } \\
\text { weight loss }\end{array}$ & nodular $\quad \mathrm{IS}_{6}$ & obstructiion & radiation & $9^{\text {mo. }}$ expired \\
\hline Case 5 & 63 & M & $\begin{array}{l}\text { cough } \\
\text { fever }\end{array}$ & nodular $\mathrm{rS}_{6}$ & inflammation & chemotherapy no & $11^{\mathrm{mo}}$ expired \\
\hline
\end{tabular}

Table 2. Sampling methods of giant cell carcinoma of the lung

\begin{tabular}{|l|c|c|c|c|}
\cline { 2 - 5 } \multicolumn{1}{c|}{} & Bronchial brushing & Transthoracic aspiration & Sputum & Histopathological basis \\
\hline Case 1 & + & & - & thoracotomy, autopsy \\
\hline Case 2 & + & & + & thoracotomy \\
\hline Case 3 & + & & & biopsy of meta. focus \\
\hline Case 4 & + & & + & \\
\hline Case 5 & - & & & \\
\hline
\end{tabular}

主気管支や区域支に腫瘤，閉塞をみたもの 3 例， 炎症所見のみのものは 2 例である。うち 1 例は 擦過細胞診が陰性のため経皮的肺穿刺法が施行 されている.

診断根據となった病理組織学的検查は, 切除 例, 開創照射 (試験切除) 後死亡した剖検例, 転 移巣生検例が夫々 1 例づつで, 残る 2 例は細胞 診断学的に巨細胞癌と診断したものである.

治療は，種々にわたり，放射線治療 3 例，广 ち 1 例は開創照射が行われている。他は, 化学 療法 1 櫺，切除例 1 例となっている.

初発症状出現から死亡までの期間は, 葉切後 7 力月の生存例を除いて, 3 力月から 13 力月で
平均生存月数は 9 力月である.

b). 検索方法

細胞形態学的に出来る限り新鮮癌細胞を検索 の対象とするため, 放射線治療, 化学療法施行 以前の気管支鏡下擦過細胞診 4 例, 経皮的肺穿 刺細胞診 1 例について検討した。

染色は, Pap 染色, Giemsa，染色，PAS 染色， 時に Mucicarmin 染色, Alcianblue 染色を行な い観察した。

III. 成

直接的採取法によってえられた癌細胞は，い づれも大部分は，孤立散在性であるが，同一標 
本中にも数コの細胞集団として認められること もある。

夫々の症例についてえられた細胞像の所見を まとめ, 病理組織学的所見を併記すると,

症例 1,70 才, 女

胸部 X線上，左下葉結節性除影から採取され た細胞は, 孤立散在性で, 集合ないし重量性を 有する癌細胞はみられない。細胞形態は多形性 に富み, 線維形から多角, 円型であり, 巨大か つ奇怪である。細胞質は, 泡沫状淡青色で, 辺 縁は明瞭である。核は偏在性で多核型は数が乏 しく, むしろ分葉型, 出芽型が大部分を占め, 核縁は，不規則で，核クロマチンは，粗顆粒状 で，核小体は円型かつ小で数コみられる：有系 分裂像もしばしばみられる。PAS染色では, PAS 陽性顆粒が，びまん性に細胞質を充満している 癌細胞像がみられるが, PAS 院性細胞も略半数 に観察された(Fig.1).

病理組織学的には, 間質の極めて乏しい線維 型，紡錘型癌細胞が主体で多形性に富み，細胞 間結合に乏しく，かつ多核巨細胞が散在し，有 糸分裂像がしばしば散見された。核異型も高度 である(Fig.2).

症例 2,41 才, 男

胸部 X 線上, 右上葉の結節性陰影で, 擦過細 胞診によって採取された細胞は, 多数の多核白 血球の中に大小不同の著しい, 径25〜50 する多角〜円形細胞が散在している。いづれも 細胞間結合に乏しく集合性はみられない。細胞 は多形性に富み, 辺縁は不明瞭で淡青色泡沫状 で，核は，多核ないし分葉型をなし，核の辺縁 は，陷凹，くびれが著しい，核クロマチンは， 粗顆粒状で, 核小体は, 円型かつ大で数コみら れる。この症例では, Cytophagocytosis が著明 で数多くみられ, 有系分裂像もみられる. PAS 反応標本でみると, 癌細胞の略半数は, びまん 性に細胞質内に細顆粒状を示す陽性物質が含ま れている(Fig. 3).

病理組織学的には細胞間結合の極めて疎な多 角細胞と多核, 単核巨細胞が混在し, 癌胞巣の 内部にまで多核白血球の浸潤が著明で，いわゆ るCytophagocytosis も多くみられる。
Fig. 1. Case 1. Note dispersed spindle cancer cells (Pap. ×400).

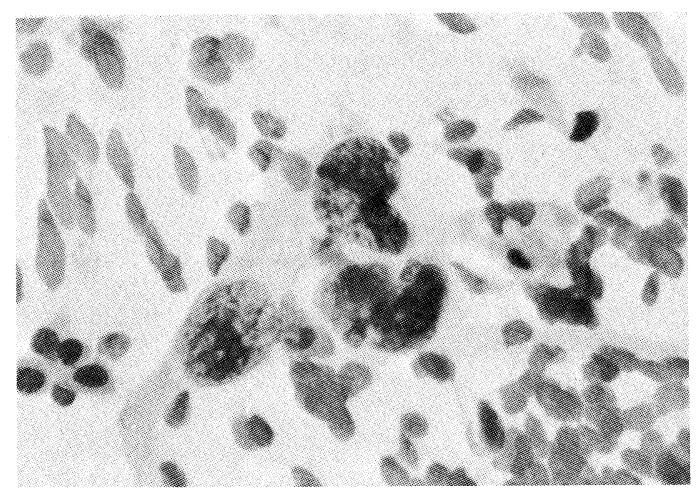

Fig. 2. Case 1. Histopathological diagnosis is giant cell carcinoma. Fiber cells spindle cells and multinucleated giant cells in poorly stroma $(\mathrm{HE} \times 100)$.

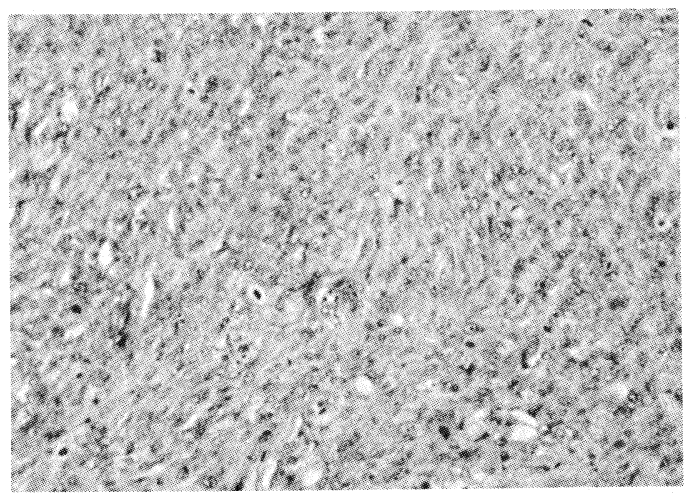

Fig. 3. Case 2. Bizzare binucleated giant cells and cytophagocytosis are observed (Pap. x 400).

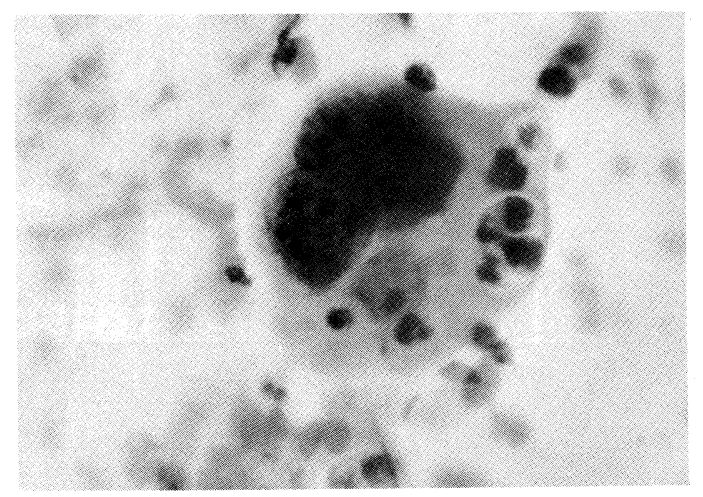


Fig. 4. Case 2. Histopathological diagnosis is giant cell carcinoma. This shows loose intercellular junction and dispersed multinucleated and uninucleated giant cells. Cytophagocytosis are observed $($ HE $\times 100)$.

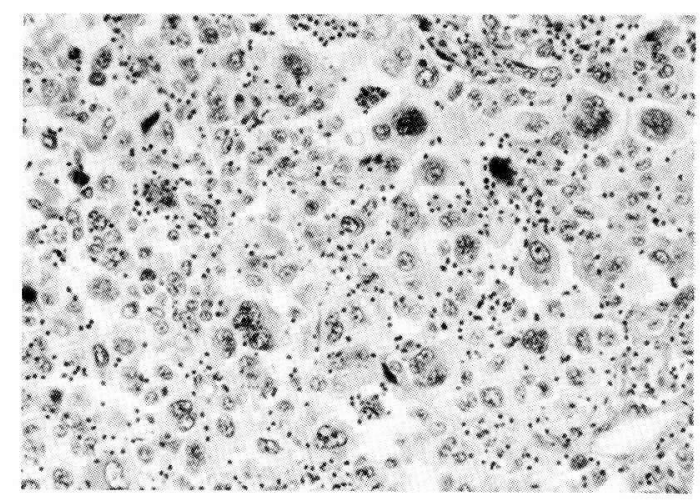

Fig. 5. Case 3. Dispersed multinucleated giant cells. Chromatin pattern is rather dense (Pap. ×400).

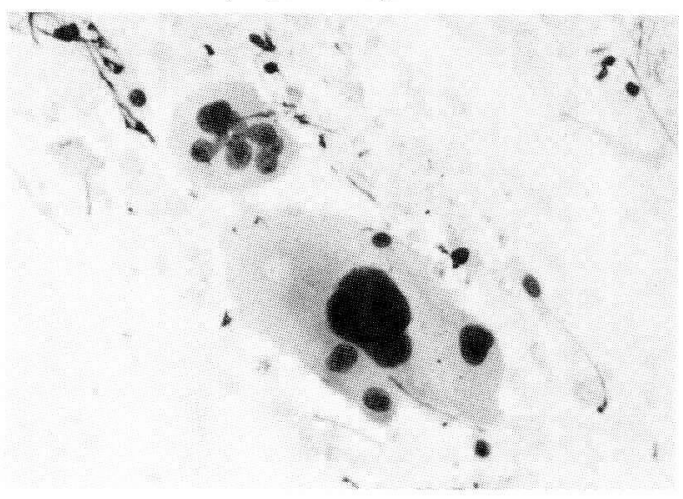

Fig. 6. Case 3. Histopathological diagnosis is giant cell carcinoma. Spindle and multinucleated giant cells in fibrous stroma are observed. Biopsy specimen of metastasis $(\mathrm{HE} \times 100)$.

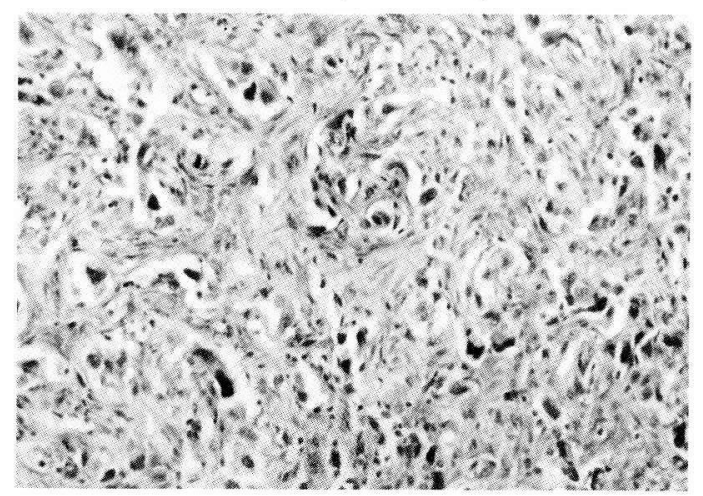

Fig. 7. Case 4. Bizzare multinucleated giant cells showing cytophagocytosis (Pap. $\times 400)$.

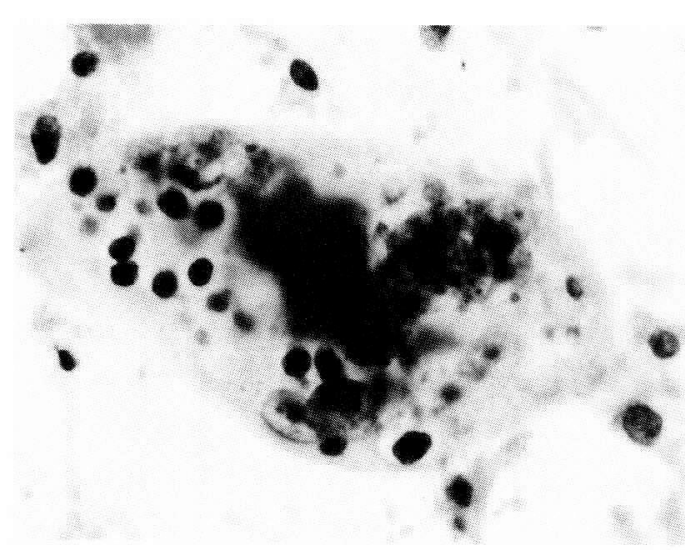

Fig. 8. Case 4. Note multinucleated giant cells with nuclear budding and round and large nucleoli (Pap. $\times 400$ ).

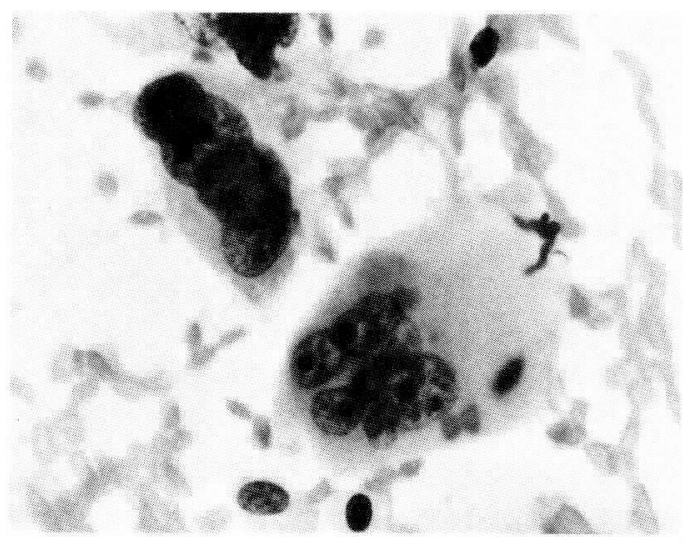

Fig. 9. Case 5. Note dispersed multinucleated giant cells and nuclear budding (Pap. $\times 400$ ).

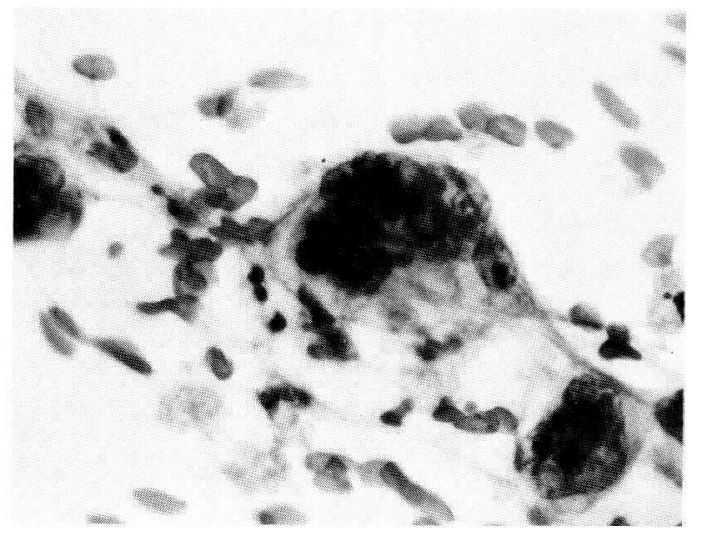


Table 3. Morphogical characteristics of giant cell

\begin{tabular}{|c|c|c|c|c|}
\hline & Multinucleated & Uninucleated & Cytophagocytosis & Mitosis \\
\hline Case 1 & + & + & - & + \\
\hline Case 2 & ++ & + & ++ & + \\
\hline Case 3 & ++ & ++ & ++ & - \\
\hline Case 4 & ++ & + & ++ & ++ \\
\hline Case 5 & + & + & - & + \\
\hline
\end{tabular}

$\mathrm{WHO}$ 組織分類の大細胞癌の一型である巨細胞 型に合致する症例である (Fig. 4).

症例 3 , 63才, 男

胸部 X線上, 右上葉に結節性陰影が存在し, 気管支擦過標本では, 孤立散在性の奇怪な細胞 形態を示す多核巨細胞と, 細胞間結合のやや乏 しい多角〜円形細胞の集合とから成立っている。 前者は, 単一細胞として散在してみられ, 最大 径 $62 \times 130 \mu$ に及゙た大細胞としてみられる。多 核形成も多く細胞の略中央部に核は集合してい る場合が多く, 核クロマチンの増量が著明で, 細胞質は淡青色である。核小体は，円型かつ小 である.PAS反応は陰性である(Fig. 5).

病理組織学的には, 線維性間質の中に, 紡錘 型の癌細胞と奇怪な形態を示す核クロマチンの 著しく増量した巨細胞がみられる。この組織像 は, WHO 組織分類の大細胞癌の一型である巨細 胞型に該当するものである (Fig. 6).

症例 4,54 才, 男

胸部 X線上, 左下葉に結節性陰影が在存し, 気管支擦過標本では，壊死背景がみられず， 17

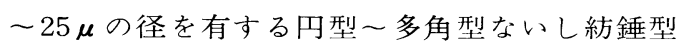
の癌細胞の集合がみられる。その中に, 孤立散 在性に多核巨細胞が多数混在し，その大きさは $37 \times 40 \mu$ から $62 \times 112 \mu$ に達する奇怪な巨細胞で, 数コの核は, 偏在性ないし中心性で, しばしば 分葉を形成しているもの存在する。また，癌細 胞や白血球の細胞質内封入が散見されるが, debrisの如き封入物質も観察された。なお，有系 分裂像は $2 \sim 3$ 視野 (200倍)に平均して 1 コ程度 みられた。PAS染色では粗顆粒状の PAS 陽性物
質が，核の周辺あるいは細胞膜に近接してみら れるものが多かった (Fig. 7, Fig. 8).

症例 5,63 才, 男

胸部 X線上, 右下葉に結節性除影が存在し, 経皮的肺穿刺法により採取された細胞は, 壊死 背景が軽度にみられ, 癌細胞は散在性で多形性 に富み，円形〜多角形を示している。多核巨細 胞は多数の円形核を有し，核小体は円型である。 また，debris の封入もみられる。単核巨細胞の 多くは核が分葉状を呈し, 極めて不整形で, 陥 凹，くびれ，出芽所見がしばしば観察された。 核縁は均等で肥厚を欠いている.PAS反応は㓌 性である(Fig. 9).

以上 5 症例の肺巨細胞癌 (切除肺 1 , 開胸生検 1 , 転移巣 1 , 細胞診 2$)$ の新鮮細胞について, その特徵的所見として, 第 1 に多核及び単核の 巨細胞, Cytophagocytosis, 有糸分裂像が挙げ られるので,これらを包括的にTab. 3 に示した。 症例 1 , 症例 5 では単核巨細胞が優勢であり,

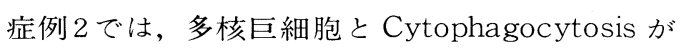
優勢である。症例 3 では, 多核及び単核巨細胞, Cytophagocytosis のいづれもが著明であり，症 例 4 では, 多核巨細胞が優勢であり, Cytophagocytosis, 有系分裂像も著しい.

次に, 細胞形態学的に癌細胞の巨細胞型所見 以外の細胞多形性, 細胞質, 核, 核小体などの所 見を日本肺癌学会による肺癌細胞型分類 (1975) の細項目に基準をおいて観察すると Tab. 4-1, Tab. 4-2 に示すようになる。これらの項目から 共通した特徵的所見を選択すると, 細胞は, 先 づ，大小不同性が極めて著しく，その大きさが, 
Table 4-1. Cytogical findings in giant cell carcinoma of the lung

\begin{tabular}{|c|c|c|c|c|c|c|}
\hline & \multicolumn{5}{|c|}{ (giant cell excluded) } \\
\hline & & Case 1 & Case 2 & Case 3 & Case 4 & Case 5 \\
\hline \multirow{6}{*}{ 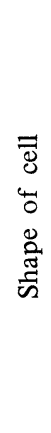 } & Arrangement & dispersed & dispersed & dispersed & dispersed flatt & dispersed \\
\hline & Anisocy tosis & + & H & H & + & + \\
\hline & Pleomorphism & H & H+ & H+ & H+ & +\# \\
\hline & $\begin{array}{l}\text { Intercellular } \\
\text { junction }\end{array}$ & loose & loose & loose & slightly loose & loose \\
\hline & Form & $\begin{array}{l}\text { round } \\
\text { spindle } \\
\text { fiber }\end{array}$ & $\begin{array}{l}\text { round } \\
\text { polygonal }\end{array}$ & $\begin{array}{l}\text { round, } \\
\text { polygonal } \\
\text { cuboidal }\end{array}$ & $\begin{array}{l}\text { polygonal } \\
\text { spindle }\end{array}$ & $\begin{array}{l}\text { round } \\
\text { polygonal }\end{array}$ \\
\hline & Ridge & clear & unclear & clear & clear & clear \\
\hline \multirow{3}{*}{ 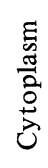 } & Staying reaction & pale blue & pale blue & pale blue & pale blue & light brown \\
\hline & Property & foamy & foamy & foamy & foamy & rather deuse \\
\hline & $\mathrm{N} / \mathrm{C}$ ratio & + & H & H+H & H & H \\
\hline
\end{tabular}

Table 5. Differential diagnosis of various tumors with multinucleated giant cells.

\begin{tabular}{|c|c|c|c|c|c|}
\hline & $\begin{array}{c}\text { Rhabdomyo Sa. } \\
\text { (pleomorphic) }\end{array}$ & Chorioca. & $\begin{array}{c}\text { Osteo Sa. } \\
\text { (pleomorphic) }\end{array}$ & Epidermoid Ca. & Histiocy te \\
\hline 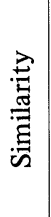 & $\begin{array}{l}\text { pleomorphic, } \\
\text { rich chromatin } \\
\text { with finely or } \\
\text { coarsely granular, } \\
\text { foamy cytoplasm }\end{array}$ & $\begin{array}{l}\text { necrotic \& hemorrhagic } \\
\text { background, } \\
\text { thin nuclear border, } \\
\text { rich chromatin, } \\
\text { distinct nucleolus }\end{array}$ & $\begin{array}{l}\text { lobulated nucleus } \\
\text { indented nuclear } \\
\text { border, } \\
\text { distinct nucleolus }\end{array}$ & $\begin{array}{l}\text { necrotic back } \\
\text { ground } \\
\text { anisokaryosis, } \\
\text { poor epithelial } \\
\text { junction }\end{array}$ & $\begin{array}{l}\text { no characteristic } \\
\text { arrangement of } \\
\text { multinucleus, }\end{array}$ \\
\hline 导 & $\begin{array}{l}\text { elongated spindle } \\
\text { cell, } \\
\text { no lobulated } \\
\text { nucleus, } \\
\text { no epithelial } \\
\text { junction }\end{array}$ & $\begin{array}{l}\text { gigantic }(50 \sim 150 \mu) \\
\text { multinuc leated cells, } \\
\text { fine chromatin } \\
\text { concentrated } \\
\text { nucleus }\end{array}$ & $\begin{array}{l}\text { a large number of } \\
\text { multinucleated } \\
\text { cells, } \\
\text { no distinct nuclear } \\
\text { border, } \\
\text { fiber cell like, } \\
\text { N/C ratio large, } \\
\text { thick cytoplasm, } \\
\text { no epithelial } \\
\text { junction }\end{array}$ & $\begin{array}{l}\text { keratinization } \\
\& \text { concentrated } \\
\text { nucleus, } \\
\text { thick cytoplasm } \\
\text { degenerative } \\
\text { process of } \\
\text { cells }\end{array}$ & $\begin{array}{l}\text { isocy totic } \\
\text { multinucleated } \\
\text { cells, } \\
\text { normal nucleated } \\
\text { chromatin, } \\
\text { usually single, } \\
\text { phagocy tosis } \\
\text { with carbon } \\
\text { pigment }\end{array}$ \\
\hline
\end{tabular}

$12.5 \mu$ から $100 \mu$ を超える広範囲にひろがり, 形 も多角, 円形から紡錘ないし線維形と種々で, かつ，多形性に富む。細胞間結合は疎で，集合 性に乏しいことが特徵的である。また，核型は， 上述のように分葉型, 陷凹型, くびれ型が大多
数を占め, 出芽型もしばしば観察される。核縁 はうすい。核クロマチンは, 顆粒状で, 微細か ら粗大にいたるまでさまざまで，核小体は円型 かつ小型で数コみられることがやや特徵的な所 見である。その他, 標本背景に壊死物質や多核 
Table 4-2. Cytological findings in giant cell carcinoma of the lung

(giant cell excleuded)

\begin{tabular}{|c|c|c|c|c|c|c|}
\hline & & & & & \\
\hline & & Case 1 & Case 2 & Case 3 & Case 4 & Case 5 \\
\hline \multirow{5}{*}{$\begin{array}{l}\frac{\mathscr{J}}{\mathrm{d}} \\
\frac{\mathrm{d}}{\mathrm{J}} \\
z\end{array}$} & Location & $\begin{array}{l}\text { periphery } \sim \\
\text { central }\end{array}$ & periphery & periphery & periphery & periphery \\
\hline & Form & $\begin{array}{l}\text { lobulation } \\
\text { buadding }\end{array}$ & $\begin{array}{l}\text { lobulation } \\
\text { indentation }\end{array}$ & $\begin{array}{l}\text { lobulation } \\
\text { round }\end{array}$ & $\begin{array}{l}\text { constriction } \\
\text { round }\end{array}$ & $\begin{array}{l}\text { lobulation } \\
\text { budding } \\
\text { indentation }\end{array}$ \\
\hline & Anisokaryosis & H & +H & H+ & H & H \\
\hline & Nuclear ridge & thin & thin & thin & thin & thin \\
\hline & Chromation pattern & $\begin{array}{l}\text { coarsely } \\
\text { granular }\end{array}$ & $\begin{array}{l}\text { coarsely } \\
\text { granular }\end{array}$ & fine granular & fine granular & $\begin{array}{l}\text { coarsely } \\
\text { granular }\end{array}$ \\
\hline \multirow{3}{*}{$\begin{array}{l}\stackrel{0}{3} \\
\frac{0}{0} \\
\frac{0}{3} \\
z\end{array}$} & Form & round & round & round & round & round \\
\hline & Size & small & large & small & large & small \\
\hline & Number & several & several & single & single & several \\
\hline \multirow{4}{*}{$\frac{\stackrel{\infty}{\omega}}{\stackrel{5}{5}}$} & Back ground & - & leucocyte & - & - & necrosis \\
\hline & Gland-like pattern & - & - & - & - & - \\
\hline & Vacuole & - & - & + & + & + \\
\hline & PAS reaction & + & + & + & + & + \\
\hline
\end{tabular}

\begin{tabular}{|l|l|}
\hline \multicolumn{1}{|c|}{$\begin{array}{c}\text { Laughans } \\
\text { giant cell }\end{array}$} & Giant cell Ca. \\
\hline $\begin{array}{l}\text { necrotic back } \\
\text { ground (caseous } \\
\text { necrosis) }\end{array}$ & $\begin{array}{l}\text { multi mucleated } \\
\text { uninucleated } \\
\text { giant cells, } \\
\text { round \& spindle } \\
\text { cells, } \\
\text { pleomorphism, } \\
\text { lobulated nuclei, } \\
\text { mitosis, } \\
\text { eccentric } \\
\text { multinuclei } \\
\text { junction }\end{array}$ \\
\hline
\end{tabular}

白血球のみられるは 5 例中 2 例であった。PAS 反応標本でみると, 細胞質内に顆粒状でかつび まん性に分布した陽性物質をみる例があった。 空胞形成は 1 例を除いて全例にみられるが，小 空胞から大空胞にいたるまでその大きさは種々
である.。

鑑別診断の上で注目すべき最も顕著な多核巨 細胞を中心に日常，肺の細胞診上とくに問題と なりうる細胞について検討した。Tab. 5 に示す ように，上皮性腫瘍として扁平上皮癌細胞，悪 性絨毛上皮腫細胞，非上皮性腫瘍としては，横 紋筋肉腫細胞, 骨肉腫細胞, その他ラングハン 又型巨細胞，組織球などについてそれぞれ類似 点と差異点に言及した。非上皮性腫瘍について は鑑別診断が困難な場合もあるが，各々の腫瘍 や疾患から由来する細胞を多数観察することに より細胞同定は可能であると考えられる。

また, 肺巨細胞癌は, 病理組織学的に腺癌の 未分化型との考え方がある。事実，腺癌型への 移行所見の存在することから, 細胞診上, 腺癌 細胞としか診断しえない場合がある。肺巨細胞 癌と診断すべきか，低分化腺癌と診断すべきか いづれが妥当であるかについては，多核，単核 巨細胞の出現優勢程度によって鑑別するのが現 状では適切であると考える。

\section{IV. 考案}

肺巨細胞癌は，1958年 Nash \& Stout ${ }^{1)}$ の 5 例 
の報告によってはじめてこの名称が付されたも ので，その後，症例報告が年次を追って発表さ れている。そして, 全身症状の顕著なことや, 転移が多臓器にわたり, 通常, 比較的転移の少 ない心，萊，腎，胃などにもしばしば転移がみ られた例が記載されている。従って他の組織型 よりも切除率が遙かに低いことが挙げられている。 病理組織学的には, Hellstrom ${ }^{3)}$ は, 17例の肺 巨細胞癌について詳細な記載をしているが, 細 胞形態学的には, 巨細胞, 円形細胞, 紡錘型細 胞からなり，構造は横紋筋肉腫に類似している。 Ozzello ${ }^{11)}$ は, 切除材料で肺巨細胞癌と診断した 症例の組織培養から 7 日目に明らかな上皮性増 殖像を観察し，その中に多核巨細胞の存在して いることを証明した。細胞診上，自験例にもみ られる特異的と考えられる多数の巨細胞の出現 や Cytophagocytosis の所見については, Naib, ${ }^{12)}$ Pfitzer, ${ }^{13)}$ Broderick ${ }^{14)}$, 松田 ${ }^{15)}$ もこれを支持して いる.Broderick ${ }^{14)}$ は 2 核や多核巨細胞と不規則 に分布する核クロマチン, 微細な空胞形成と細 胞間結合の疎なることを特徵として挙げ，集合 性，角化傾向がなく貧喰能を有する孤立性巨細 胞があったら巨細胞癌と診断されるべきとのべ ている. Pfitzer ${ }^{13)}$ も気管支鏡下にえられた細胞 像について全く同様の所見を記載している。ま た彼らは，多核巨細胞は不完全有系分裂の結果 として未分化腫瘍にもみられ，また，抗癌剤に よる変性像としてもみられるので巨細胞癌の診 断は, 放射線治療, 化学療法剂投与以前につい て診断しないと䛊診の危険が生ずると述でてい る。単核巨細胞は, 核の多形性, 変形性が著し く, 分葉型, 陥凹型, 出芽型, くびれなど永田 ${ }^{16)}$ により提唱されている 5 型の大部分が観察され， 巨細胞癌の未分化性を表現していると考える。 松田ら ${ }^{15)}$ は, 10症例の肺巨細胞癌について細胞 学的に詳細な観察を行ない，その特徵としてと くに壊死背景, 細胞貧喰, 多核巨細胞の Cyto phagocytosis などを挙げ, 建石ら ${ }^{17)} は$ Cytophagocytosis を超微形態学的に検索し, 巨細胞の Intracytoplasmic microcyst の拡大せる腔へ他 の癌細胞が入りこんだものと考えている。さら にまた, 腺癌, 大細胞癌と鑑別困難な症例のあ
ることにもふれている。事実, 巨細胞癌の entity を拡大して評価すると，上述の 2 つの組織型と混 乱してくる可能性があり, 現状では客観的に明白 な症例のみを取扱うのもやむをえないであろう。

肺巨細胞癌と鑑別診断上挙げられる細胞所見 は，表 5 のようであるが，Naib ${ }^{12)}$ は細胞の大き さの著しい違い, 有系分裂像, クロマチン凝集, 巨大多核細胞の出現，細胞質の角化現象，核濃 縮についての異同点を述でている.Pfitzer ${ }^{13)}$ は, Histiocyte に似た巨細胞の存在にふれているが, 自験例について同様の細胞観察から Histiocyte と同定しうる細胞であると考えている。また， Guillan $^{5)}$ は, Rhabdomyoblst, Lipoblast, Osteoblastに類似形態が求められる点を述べているが, 事実，鑑別診断上，かなり困難な場合がありう ることは日常経験する所である。

有系分裂細胞の多いことも未分化性を強く示 唆していると考えるが，自験例でも一視野(中等 度拡大) $2 \sim 3$ ב観察された症例もあり，増殖が 速かであったことを反映しているものと考える。

組織球，ラングハンス型巨細胞，その他各種 の多核巨細胞について細胞診の立場から，森脇 ら ${ }^{18)}$ は，多面的，総合的に詳細な記述をしてい る。肺巨細胞癌については，その由来，背景に 尚，未解決な点が残されているのが事実で，さ らに多くの症例について系統的な検討を重ねて ゆかねばならない。

\section{V．むすび}

1). 肺巨細胞癌 (病理組織学的診断 3 例, 細胞 診 2 例)について, 気管支擦過細胞診 4 例, 経皮 的肺穿刺細胞診 1 例の新鮮癌細胞所見をのべた。

2).本型における特異的細胞所見は，多数の 多核, 単核巨細胞の出現で, かつ, 多形性に富 み, 径 $100 \mu$ 以上に達する巨細胞もみられた。Cytophagocytosis, 有系分裂像の多いことも副次 的特有な所見として挙げられる。

3)。細胞構造上, 細胞間結合がそしく, 従っ て，孤立散在性で，核に分葉型，陥凹型，出芽型， くびれなど核多形性が観察され，核クロマチン は，粗顆粒状傾向を有し，核小体は， 1 ～数コ みられ，多くの細胞は，PAS 反応陽性である。 
1) Nash, A.D., \& Stout, A.P. Cancer, 11, 2: 369-376, 1958.

2) Bendel, W.L., \& Ishak, K.G. Am. J. Clin. Path., 35, $5: 435-440,1961$.

3) Hellstrom, H.R., \& Fisher, E.R. Cancer, 16, 8 : 1080-1088, 1963.

4) Flanagan, C.P., \& Roeckel,I.E. Am. J. Med., 36: 214-221, 1964.

5) Guillan, R.A., \& Zelman,S. Am. J. Clin. Path.,46, $4: 427-432,1966$.

6) Herman, D.L., Bullock, W.K. \& Waken, J.K. Cancer, 19: 1337-1346, 1966.

7) Lerner, H.J. Arch. Surg., $94: 891-894,1967.1$

8) Razzuk, M.A., Lynn,J.A., Kingsley, W.B., Race, G. J., Urschel, H.C.C., \& Paulson,D.L. J. Thorac. Cardiovasc. Surg., 59, 574-580, 1970.

9) Ioachim, H.L. Lab. Invest., 14, 10 : 1784-1794, 1965.
10) Kreyberg, L. Histological typing of lung tumours. WHO, Geneva, 1967.

11) Ozzello, L., \& Stout, A.P. Cancer, 14, $5: 1052$ 1056, 1961

12) Naib, Z.M. Dis. Chest, $40: 69-73,1961$.

13) Pfitzer, P., \& Knobligh, P.G. Acta Cytologica, $12: 3,256-261,1968$

14) Broderick, P.A., Corvese, N.L., LaChange, T. \& Allard, J. Acta Cytologica, 19:3, 225-230, 1975.

15）松田 実・宝来 威：肺癌 $13,4: 317-324,1973$.

16）永田哲士：細胞学大系 5 , 増殖と分化, 朝倉書 店 昭 46.1

17）建石竜平・松田 実・寺沢敏夫・服部正次: 癌の臨床 15, 7:603-614, 1969 .

18）森脇昭介 - 宇佐美孝子 - 山本陽子 - 山内政之 · 村上和重：日臨細胞誌 15, 2: 83-96, 1976. 


\title{
Giant cell carcinoma of the lung
}

\section{A cytological evaluation}

\author{
Kinya Sawada M.D., et al.
}

Chiba cancer center

In 1958, Nash and Stout called attention to a type of primary lung cancer comprised principally of giant cells and variable focuses of anaplastic frequently mesenchymal-like components resembling rhabdomyosarcoma or osteosarcoma.

Giant cell carcinoma of the lung occurred at a younger age, exhibited widespread metastases, and pursed a more rapid, fulminant course than histological variants. Its lower resectability rate compared to other lung carcinomas.

We studied materials before radiation and chemotherapy in five cases of giant cell carcinoma of the lung obtained by bronchoscopic brushing method and transthoracic aspiration. These materials were informative for study of fresh cancer cells.

Chest $\mathrm{x}$-ray findings in all cases a nodular shadow.

Morphological features were studied with stain methods such as Pap., Giemsa, PAS, Mucicarmin, and Alcianblue reaction.

Multinucleated and uninucleated bizzarre giant cells showed to phagocytize neutrophils, and debris and uneven dispersed distribution or a pooly cohesive groups but never in tight clusters. Occasionally cancer cells were found in necrotic substances. The cancer cells were round or smooth but showed lobulation, budding, indentation and constriction, and chromatin was coarsely or fine and rich. The nucleoli were round and small.

In differential diagnosis, we studied on similarity and difference with epidermoid carcinoma, choriocarcinoma, rhabdomyosacoma, osteosarcoma, Langhans's giant cell and histiocyte. 